\title{
Formation of Gas-Emission Craters in Northern West Siberia: Shallow Controls
}

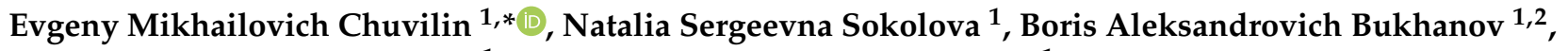 \\ Dinara Anvarovna Davletshina ${ }^{1}$ and Mikhail Yurievich Spasennykh ${ }^{1}$
}

1 Skolkovo Innovation Center, Skolkovo Institute of Science and Technology, 30, Build. 1, Bolshoi Boulevard, 121205 Moscow, Russia; n.sokolova@skoltech.ru (N.S.S.); b.bukhanov@skotech.ru (B.A.B.); d.davletshina@skoltech.ru (D.A.D.); m.spasennykh@skoltech.ru (M.Y.S.)

2 V.I. Il'ichev Pacific Oceanological Institute, Far Eastern Branch of the Russian Academy of Sciences, 690041 Vladivostok, Russia

* Correspondence: e.chuvilin@skoltech.ru

check for updates

Citation: Chuvilin, E.M.; Sokolova, N.S.; Bukhanov, B.A.; Davletshina, D.A.; Spasennykh, M.Y. Formation of Gas-Emission Craters in Northern West Siberia: Shallow Controls. Geosciences 2021, 11, 393. https:// doi.org/10.3390/geosciences11090393

Academic Editors:

Jesus Martinez-Frias and

Christina Biasi

Received: 10 August 2021

Accepted: 15 September 2021

Published: 17 September 2021

Publisher's Note: MDPI stays neutral with regard to jurisdictional claims in published maps and institutional affiliations.

Copyright: (c) 2021 by the authors. Licensee MDPI, Basel, Switzerland. This article is an open access article distributed under the terms and conditions of the Creative Commons Attribution (CC BY) license (https:/ / creativecommons.org/licenses/by/ $4.0 /)$.

\begin{abstract}
Gas-emission craters discovered in northern West Siberia may arise under a specific combination of shallow and deep-seated permafrost conditions. A formation model for such craters is suggested based on cryological and geological data from the Yamal Peninsula, where shallow permafrost encloses thick ground ice and lenses of intra- and subpermafrost saline cold water (cryopegs). Additionally, the permafrost in the area is highly saturated with gas and stores large accumulations of hydrocarbons that release gas-water fluids rising to the surface through faulted and fractured crusts. Gas emission craters in the Arctic can form in the presence of gas-filled cavities in ground ice caused by climate warming, rich sources of gas that can migrate and accumulate under pressure in the cavities, intrapermafrost gas-water fluids that circulate more rapidly in degrading permafrost, or weak permafrost caps over gas pools.
\end{abstract}

Keywords: Arctic permafrost; explosive gas emission; crater; ice-rich clay; ground ice; intrapermafrost cavity; cryopeg; methane; Yamal Peninsula

\section{Introduction}

The effects of global warming observed worldwide in recent decades are especially evident in the Arctic, including the vast territories of northern Russia. The changes in air and permafrost temperature patterns lead to progressive permafrost degradation and active layer thickening [1-5]. The degrading permafrost loses its bearing capacity as a foundation for buildings and facilities, which creates risks to the Arctic infrastructure [6-13]. Furthermore, permafrost affected by warming can promote the emission of the main greenhouse gases (methane and carbon dioxide). Greenhouse gases can be released in multiple ways, as summarized and mapped in a number of recent publications [13,14]: from emission from the surfaces of the active layer and lakes to gas flow during drilling to different depths in permafrost.

Gas emission from shallow Arctic permafrost can be explosive and produce deep craters reaching tens of meters in diameter and depth (Figure 1). The first large crater to be discovered, $\sim 40 \mathrm{~m}$ in diameter and $50 \mathrm{~m}$ deep, was located in the Yamal Peninsula (northern West Siberia) in the summer of 2014 (Figure 2, C1). It was spotted by accident from helicopter, $30 \mathrm{~km}$ south of the Bovanenkovo gas-condensate field, which had commenced operations shortly before (in 2012). That discovery was followed by many others, amounting to around 20 to date, which have been documented in more or less detail [14-26] (Figure 2). 


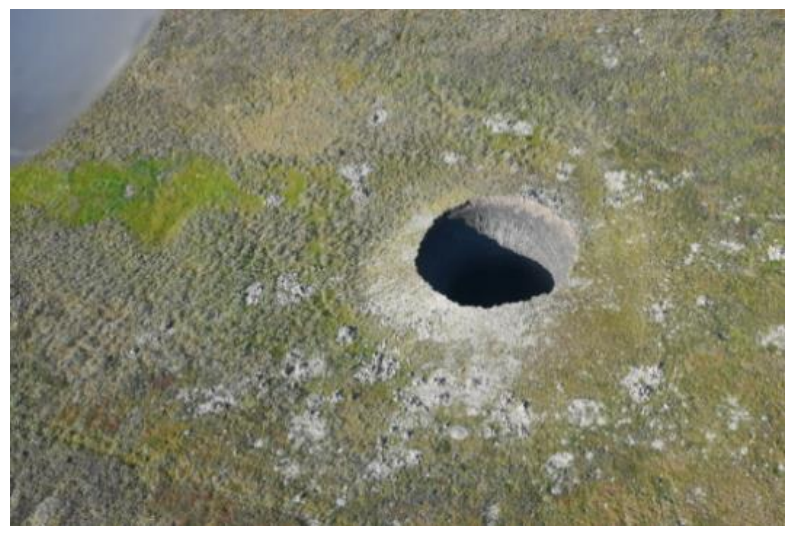

(a)

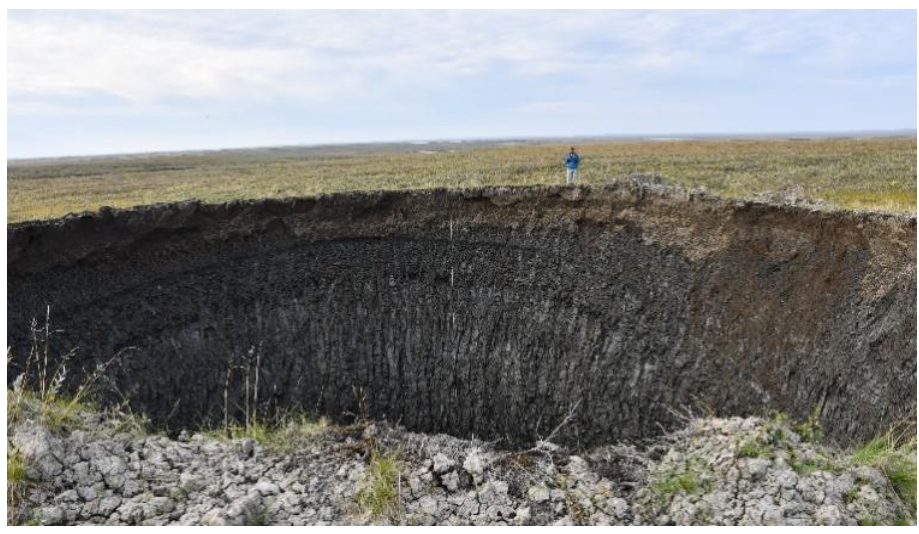

(b)

Figure 1. Crater in the Yamal Peninsula found in 2020 (C17). Views from: (a) helicopter and (b) ground surface. Photograph by E. Chuvilin.

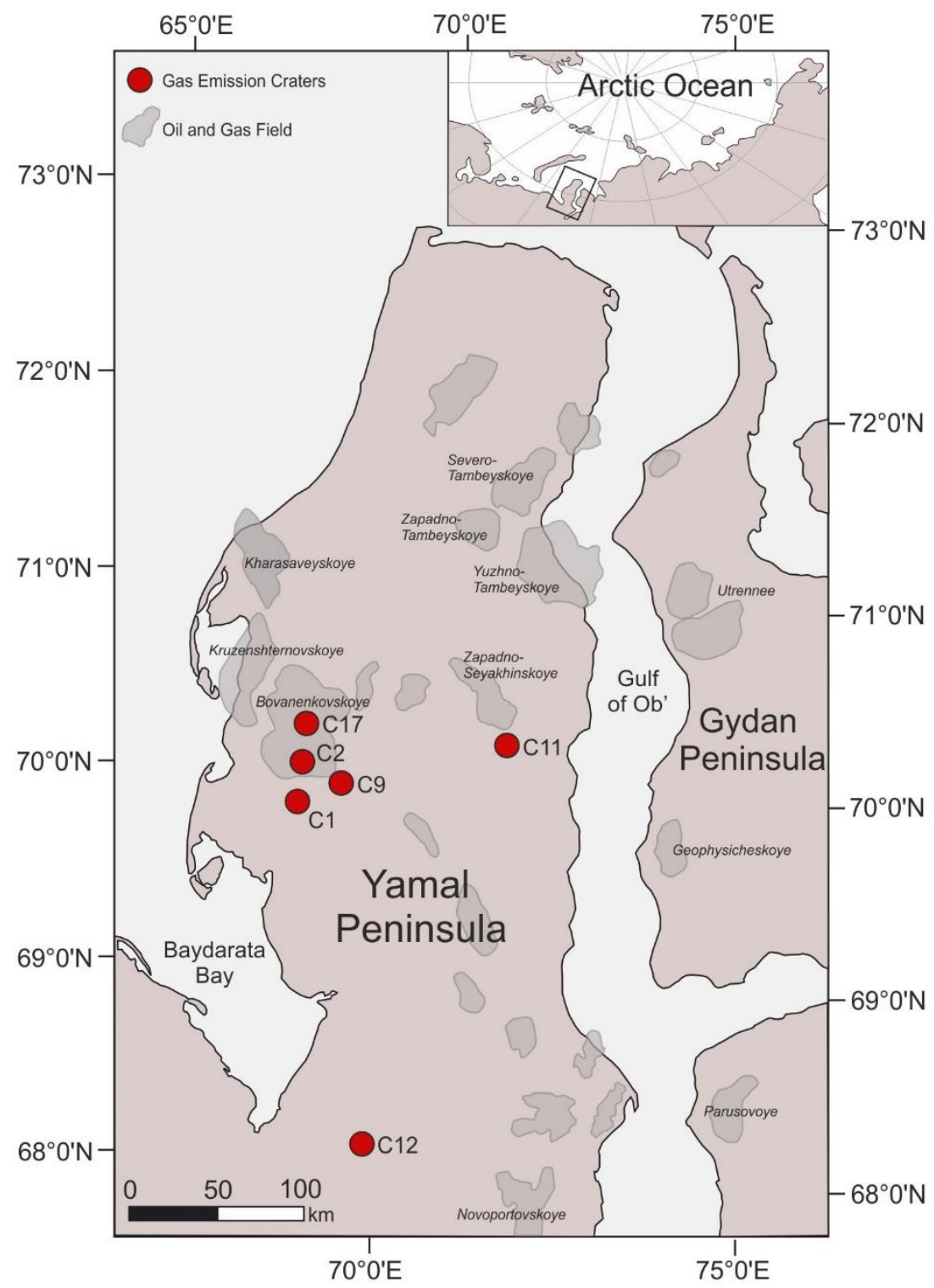

Figure 2. Location of some gas emission craters on the Yamal Peninsula. 
It is unlikely that the progressively more numerous cases of explosive gas emission from shallow permafrost, with formation of huge craters, would be due uniquely to the recent active development of the northern territories, without the impact of a warming climate and permafrost degradation. The available monitoring data reveal a large potential of degassing hazard that poses problems for human activity in the permafrost regions. Two new craters (Figure 2, C2, C9) were found quite recently: one $3 \mathrm{~km}$ away from the Bovanenkovo-Ukhta major pipeline in pressurized conditions, and another near the Obskaya-Bovanenkovo railway. The risks to petroleum infrastructure are aggravated by the violent gas emission that, according to eye-witness reports, is often accompanied by spontaneous ignition and explosion of gas and may lead to the formation of craters. As shown by the available data $[14,23-25,27,28]$, an explosive gas emission is commonly preceded by growth of pingo-like mounds (locally called bulgunnyakhs). However, unlike the classical frost heave, their growth is instead driven by pressure buildup at local accumulations of gas confined in taliks and cavities in shallow permafrost. The pressure of gas (or gas + liquid) in a closed intrapermafrost cavity may exceed the critical value and overcome the resistance of the permafrost cap. As a result, the cap collapses by pneumatic or hydro fracture-like mechanisms and its ejected fragments fall down around the crater making up a parapet-like ridge or become dispersed over distances of $300 \mathrm{~m}$ or more [29] (Figure 3). This basic crater formation model has been generally accepted by most geoscientists, but some issues remain poorly understood: e.g., the origin and dimensions of large gas-filled cavities in permafrost, the composition and nature of gas, and the magnitude of the gas pressure required to break through the frozen cap, etc.

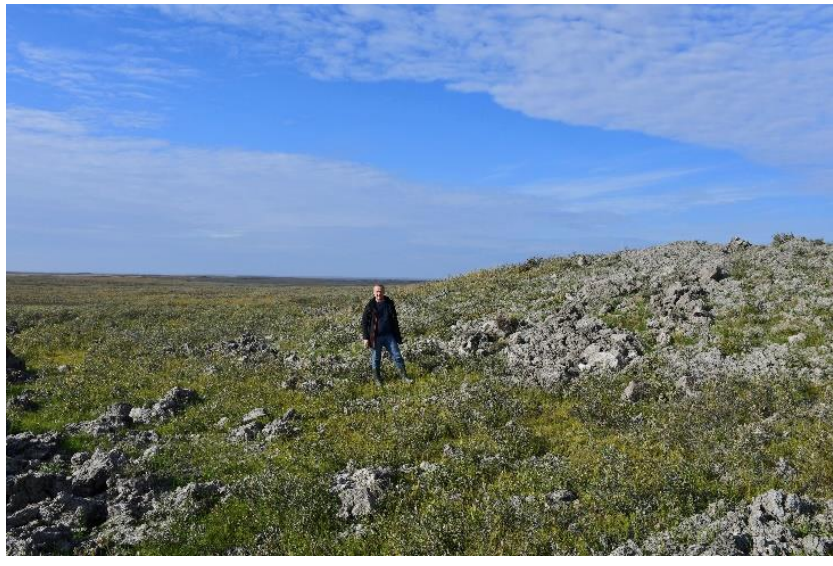

(a)

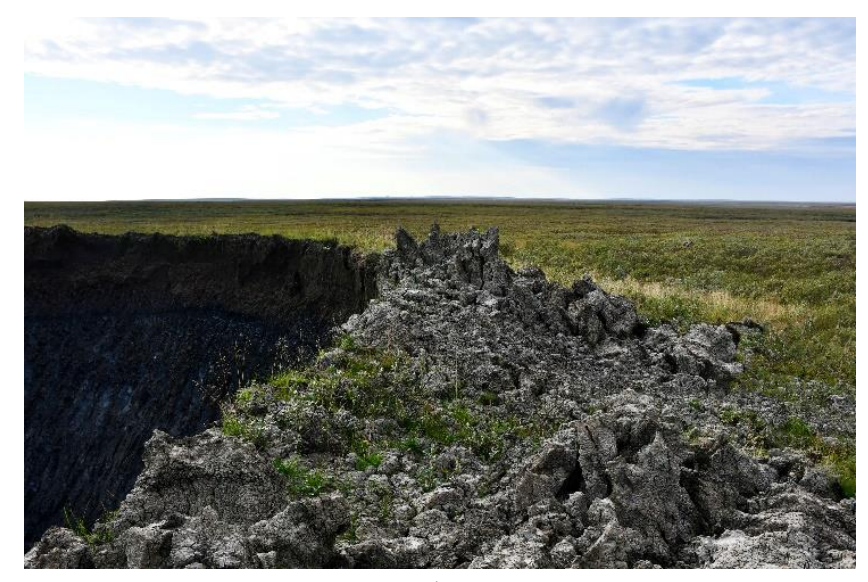

(b)

Figure 3. View around the crater (C17): (a) eastern and (b) western slopes of destroyed mound with ejected fragments. Photographs by E. Chuvilin.

The causes and mechanisms of explosive gas emissions have been explained in different models, but none of them can account for all known cases. All events of this kind produce the same visible result-a crater-but the causes of gas accumulation in permafrost and the conditions in which the process develops may differ considerably depending on local geomorphology and permafrost properties. Therefore, it will be hard to propose a reasonable method for detection and mapping of potentially pressurized gas-saturated bodies in shallow permafrost prone to explosion and cave-in in the near future. In this respect, data from new craters [29] have important implications for hazard prediction. This study focuses on near-surface factors in permafrost, that appear to be overlooked in the available publications on gas-emission craters but may be relevant to the processes discussed [30]. 


\section{Permafrost Properties in the Area of Gas-Emission Craters}

The permafrost of northern West Siberia, where gas-emission craters were found in the Yamal and Gydan Peninsulas $[13,26]$, is composed of silty and clayey marine sediments deposited at high rates in the Pleistocene [31-35]. The sediments are rich in pore ice and enclose lenses of massive ground ice [36] as large as hundreds of meters long, which are, however, not always expressed in the surface topography. Most of the ground ice is restricted to the upper $50 \mathrm{~m}$ of permafrost although some lenses occur at $100 \mathrm{~m}$ or deeper [37]. Ground ice is most often sandwiched between clayey rocks above and sandy sediments below. The clay permafrost has a reticulate cryostructure that typically forms by soft sediment freezing $[9,35,38]$.

The ice has variable chemistry and salinity ranging vertically from 0.01 to $8.5 \mathrm{~g} / \mathrm{kg}$ [39], even within a single lens. Pure ice is commonly fresher than the ice containing clay and sand inclusions, and ice-soil layers are the most saline, especially in the top parts of ice lenses, due to migration of ions from the overlying saline clay [40].

The possible formation mechanisms of massive ground ice in West Siberia have had various explanations e.g., [38,41-44]. The hypotheses for the origin of the same ice outcrop may be controversial because of complex structures, different amounts of available knowledge, and the lack of rigorous assessment criteria. The ice structure is often heterogeneous, with alternating sites and layers of pure ice and ice enriched with gas and organic-mineral compounds. Ice bodies may lie horizontally or dip slightly, almost without affecting the rocks above, but also may have appearances similar to laccoliths, stocks, or dome-shaped folds that deform the overlying permafrost $[37,38,45]$.

Many models relate the origin of massive ice to cryodiapirism, that was active early during the freezing of poorly lithified marine sediments when the Arctic seas retreated and groundwaters intruded vertically into porous sediments. The ice formed as a result of free water within freezing sediments leading to cryogenic differentiation into mineral aggregates, segregated, and massive ice, during the early diagenetic stage. The formation of ice in the Pleistocene permafrost of West Siberia by the combined segregation-injection mechanism was confirmed by the chemical similarity of ice with pore waters [39,40]. Fossil segregated ice, which resulted from injection and freezing of water when the sediments became exposed during sea level regression, differs from its modern counterpart produced by the freezing of water-saturated taliks [46]. In particular, the fossil ice leaves no traces in the surface topography and its layers or lenses can lie concordantly with the host sediments and thus survive for many thousands of years [45]. The segregated ice of the Yamal Peninsula is coeval with the associated permafrost which began growing in the latest Kazantsevo-earliest Zyryanian stage $\left(\mathrm{Q}_{\mathrm{III}}{ }^{1-2}\right)$, when the geological and cryological conditions favorable for the formation and prolonged preservation of large ice masses existed for a long period over vast regions.

In contrast, the particular structures and heterogeneity of permafrost in northern West Siberia may result from the presence of lenses and layers of cold saline water (cryopegs). The continuous permafrost that formed after the Yamal transgression [32] is more than $300 \mathrm{~m}$ thick, -3 to $-7^{\circ} \mathrm{C}$ and colder, and consists of two hydrological units: (i) frozen ice-rich sediments above making a $\sim 200 \mathrm{~m}$ thick cryogenic regional aqueclude, which has existed for tens of thousands of years and was as cold as $-20^{\circ} \mathrm{C}$ or colder in the upper part during the Pleistocene, and (ii) cold permeable rocks below. The Yamal groundwaters occur above, below, or inside the cryogenic aqueclude, and each category has its specific conditions of formation, accumulation, cryogenic transformation, chemistry, and salinity [39].

Cryopegs above the aqueclude may occur near the bottom of open taliks beneath lakes or rivers, that are no deeper than $30 \mathrm{~m}$. Taliks in river valleys often consist of two hydraulically connected layers, given that alluvium lies over saline rocks: fresh and brackish waters with positive temperatures above and saline waters with negative temperatures below [33]. 
Intrapermafrost groundwaters may exist only as low-temperature cryopegs but are never fresh, because saline permafrost in Yamal, especially in the north, spreads to depths of 150-300 m, i.e., the rocks saturated with seawater have been subject to cryogenic transformation at quite low negative temperatures. Seawater hosted by $-10{ }^{\circ} \mathrm{C}$ and colder rocks undergoes cryoconcentration to $150-180 \mathrm{~g} / \mathrm{kg}$, which produces typical Cl-Na brines, with ions of $\mathrm{Ca}, \mathrm{Mg}$, and bicarbonate, that can remain liquid even at quite low sediment temperatures. Intrapermafrost cryopegs are widespread in coastal lowlands $(0.3-3.0 \mathrm{~m}$ asl) along the western and northern shores of the Yamal Peninsula, as well as on high marine terraces. The head in such cryopegs can reach a few meters high depending on the borehole depth $[33,35,39,47]$. Tests in boreholes that strip several permafrost aquifers often show different pressure and salinity values, which may indicate the absence of connectivity between them $[9,35]$.

Subpermafrost groundwaters below the cryogenic aqueclude occur in lenses of wet sand, silt, and clayey silt. These pressurized highly saline waters of mainly Cl-Na-Ca chemistry have been found during deep exploratory drilling at almost all levels within depths from 130 to $300 \mathrm{~m}$ [39]. Generally, both intra- and subpermafrost waters are too saline and sparse to be used anyhow $[9,35]$.

The content and composition of dissolved salts in cryopegs, as well as the relative percentages of phases, are variable and depend on the temperature of the sediments [35]. Pore water becomes ever more concentrated as ice crystallizes, but the salts (except for mirabilite) remain dissolved to $-17{ }^{\circ} \mathrm{C}$, and crystallize as $\mathrm{NaCl}, \mathrm{Mg}$, and $\mathrm{Ca}$ hydrates upon further cooling. The major-ion chemistry of the Yamal cryopegs corresponds to original temperatures of -4.8 to $-25^{\circ} \mathrm{C}$, notably lower than their present temperatures [35]. The near-surface cryopegs, within the 15-20 m active layer, are affected by the present warming, whereas those below $25 \mathrm{~m}$ store a record of temperatures that maintained the cryometamorphism of seawater during the coldest Sartan stage of the Pleistocene ( 25 to 10 kyr BP): -10 to $-15^{\circ} \mathrm{C}$ at a depth of $100 \mathrm{~m}$ [48]. The cryopegs must be widespread in the Yamal Peninsula, as they are quite often encountered during drilling, with $10 \%$ of cases in positive landforms and up to $20-30 \%$ in depressions [35].

Permafrost at depths of the 100-130 m depths is saturated with gas. Gas has been reported [35] to release together with water, especially from the $30 \mathrm{~m}$ to $12 \mathrm{~m}$ depth interval, in many wells that stripped cryopegs in the Salekhard Fm. Middle Pleistocene marine sediments commonly composed of organic-rich clayey silt with silty sand interbeds were deposited during the Yamal stage $\left(\mathrm{mQ}_{\mathrm{I}-\mathrm{II}}{ }^{1-2}\right)$. Gas shows at these depths are the most frequent in wells of all types within the Bovanenkovo field $[9,49,50]$; the maximum measured gas flow reaches 14,000 $\mathrm{m}^{3}$ / day. Meanwhile, the gas emission events are less frequent, with a flow rate no more than $100 \mathrm{~m}^{3} /$ day, from the overlying Kazantsevo Fm. silt $\left(\mathrm{mQ}_{\mathrm{III}}{ }^{1}\right)$, and are almost absent from the more clayey deeper sediments below $130 \mathrm{~m}[9,49,50]$. The released gas is of biochemical origin consisting of $99 \%$ methane, with minor percentages of nitrogen, carbon dioxide, hydrogen, and some other gases.

Gas emission is quite voluminous also within the $60-80 \mathrm{~m}$ depth interval, where ordinary gas accumulations may coexist with gas hydrates. Although being above the zone of gas hydrate stability, the sediments of this interval may contain relict metastable gas hydrates, which survive due to self-preservation [51-55] at negative temperatures after the stability limits shifted under geologically- and climatically-induced changes of pressure and temperature. The metastability zone encompasses the whole permafrost interval where the temperature does not exceed the thaw point of the ground. Correspondingly, taliks and cryopegs in this zone may trigger local thawing and dissociation of metastable gas hydrates at minor global-scale permafrost warming as the climate changes. The large volumes of rising free gas liberated by the dissociation of hydrates may be released explosively from the permafrost $[9,50]$. 
The explosive gas emission from permafrost leading to the formation of large craters is often assumed to be preceded by heaving above the gas pool. However, heaves in the Yamal tundra may have other causes and grow by mechanisms not related directly to the presence of gas [56]. At least 7000 heave features have been detected in satellite images of the Yamal territory [21], many times more than the few hundred sites mapped by land surveys since the 1960s [56]. The origin of frost heaves may be associated with the formation of intrusive or segregated ice, or both. Heaves associated with back-freezing sublake taliks arise when intrusive ice forms at very low temperatures, typical of Yamal, or during mixed intrusive-segregated ice formation in warmer periods [42]. Large perennial intrusive ice features widespread in northern West Siberia result from the outpouring of subpermafrost water or by the freezing of closed sublake taliks. The same mechanisms may work for thick massive ground ice. Multiple ice intrusion events associated with cyclic freezing of the host sediments produce layered ice bodies, while dome-shaped features mark the pathways of injecting water [57]. Intrusive ice can contribute to a sort of mud volcanism in permafrost [58], or cryovolcanism [23]: as the water influx transcends a heaving area, a pingo transforms into a "hydrovolcano", with the formation of aufeis, or into a "mud volcano" ejecting water or wet mud through the fractured cap. The collapse of the cap over pressurized gas may be accompanied by water gushing meters high or the eruption of liquefied mud, or sometimes by explosions and dispersal of cap fragments. Such cryovolcanism, as a form of geological activity, is also known to occur on ice planets and planetoids [59,60]. Freezing water can heal the fractures afterwards, but cap failure and eruptions repeat if the water pressure persists. The process stops when the pressure decreases or when the cap strengthens through freezing. In the latter case, water may find other pathways and produce heave groups. The most widespread are large perennial intrusive ice features associated with back-freezing of sublake taliks.

Both fossil and modern intrusive ice varieties share a number of key features known since the 1950s [61]: clustering gas bubbles, mineral components appearing as small turbid jets of flaky fine-grained material or sand particles and pieces of clay floating in ice, and ice crystals of quite large sizes with chaotically oriented c-axes. The structure and geological position of intrusive ice bodies in the Yamal Peninsula $[37,38,45]$ indicate their origin either by single voluminous injections of relatively clear water or by repeated injections of small volumes of water with different amounts of solid particles, up to a liquefied sediment flow. The water-soil mixture freezes to become dirty ice or rock with very high ice contents. Similar features of intrapermafrost ice bodies were reported from crater sites, where it was possible to document [29] or sample [26] the ice exposed in the crater walls.

Examination of a new gas-emission crater south of the Bovanenkovo field in the central Yamal Peninsula, a month after its discovery in July 2020 [29], revealed a huge ice body, with nearly vertical ice lenses (a typical reticulate cryostructure), beneath clayey permafrost (Figure $4 a-c)$.

At the time of the observations, the crater reached a diameter of $\sim 25 \mathrm{~m}$ in the upper part and varied in depth from 29 to $33 \mathrm{~m}$ (shallowest in the center). The interface between frozen mud and massive ice was about $11 \mathrm{~m}$ below the ground surface. Therefore, the ice thickness was at least $20 \mathrm{~m}$ to the crater bottom, as is common to the bodies of massive ice in Yamal. Ice was mainly grey or locally brownish to milky-white. It has a banded appearance due to inclusions and plastic deformation. The bands were slightly domed in the upper part of the ice body, as a result of its natural growth, as well as by further transformation under gas pressure (Figure 4a). The ice surface had a molten appearance (Figure 4c), with oval pits most likely produced by the heterogeneous structure of ice and its uneven melting during the formation of the gas-filled cavity. 


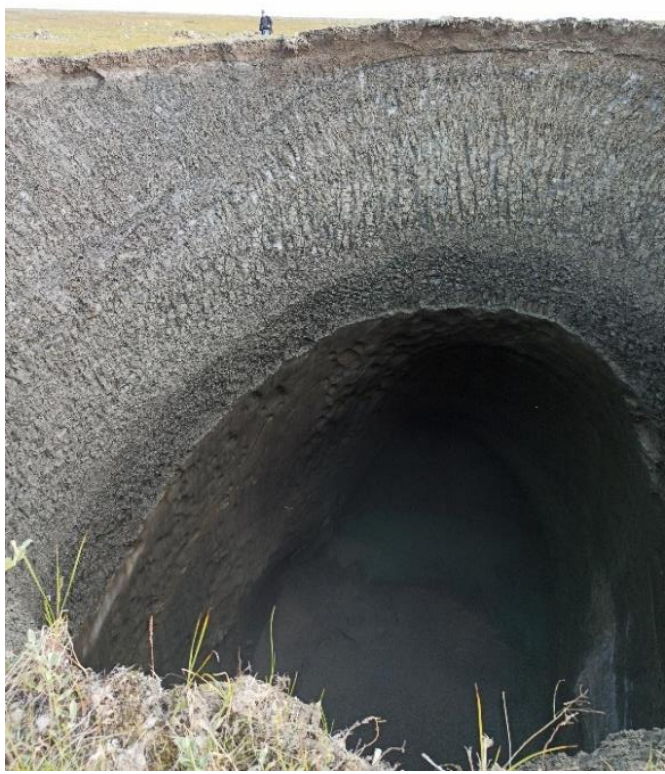

(a)

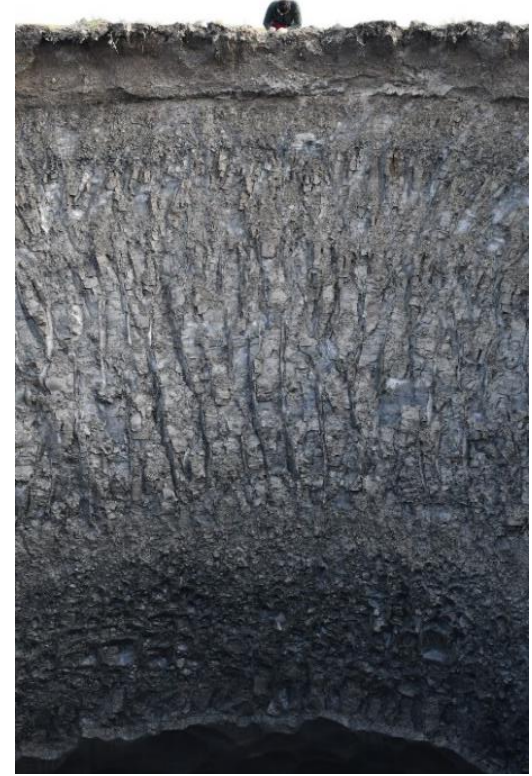

(b)

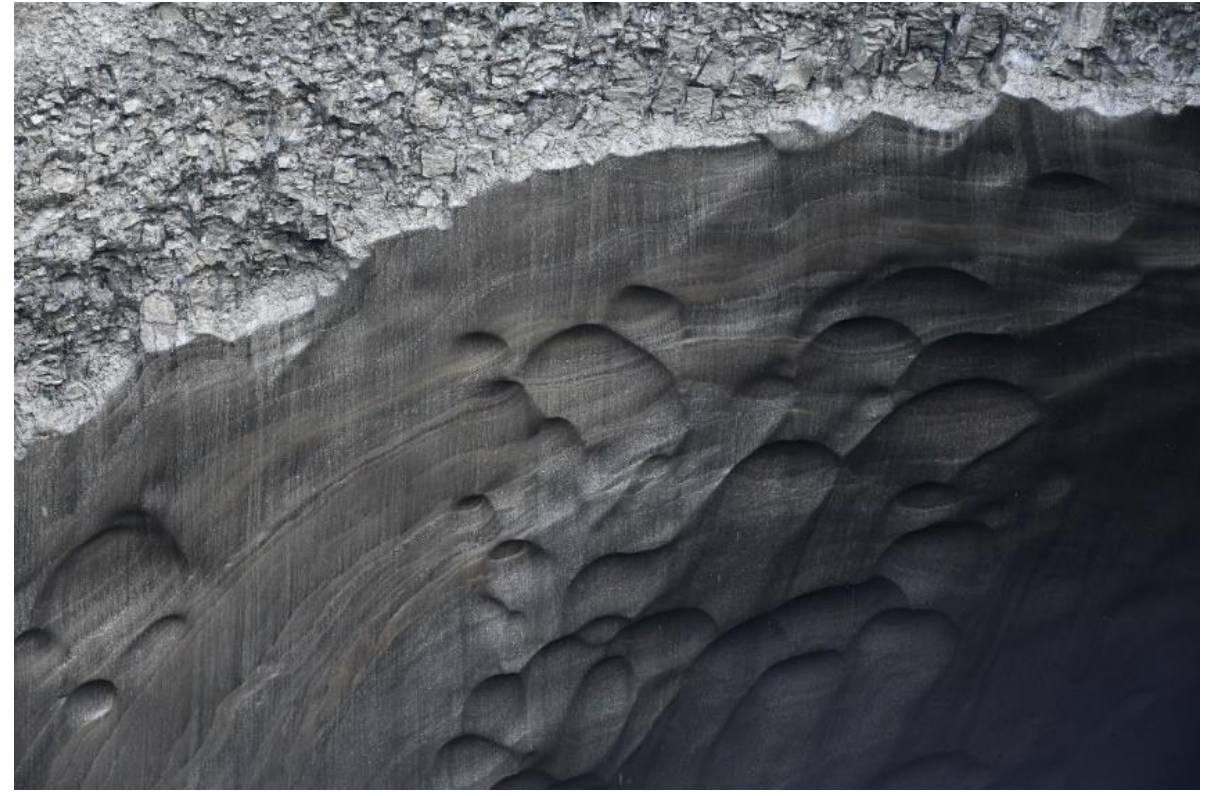

(c)

Figure 4. Gas-emission crater (C17): general view and wall fragments. Photographs by: (a) B. Bukhanov and $(\mathbf{b}, \mathbf{c})$ E. Chuvilin.

More evidence of the structure and composition of shallow ground ice was obtained through examination and sampling of a crater discovered in the Erkuta River valley (Figure 2, C12) in the southern Yamal [26]. The stripped thickness of the crater was about $4 \mathrm{~m}$, while its bottom was hidden under water that had filled the crater by the time of observations and was covered with ice. The ice was transparent and almost free from inclusions or locally enclosed flakes and 1-2 cm thick layers of fine soil (Figure 5). The clear massive ice was topped by a dirty grey ice layer, a few centimeters thick, with abundant soil inclusions. The size of the ice crystals varied from few $\mathrm{mm}$ near the contact to $7 \mathrm{~cm}$ in the samples of relatively clear ice [26]. The ice contained mm-scale gas bubbles of intricate shapes, especially abundant in the samples from the soil-rich top layer. 

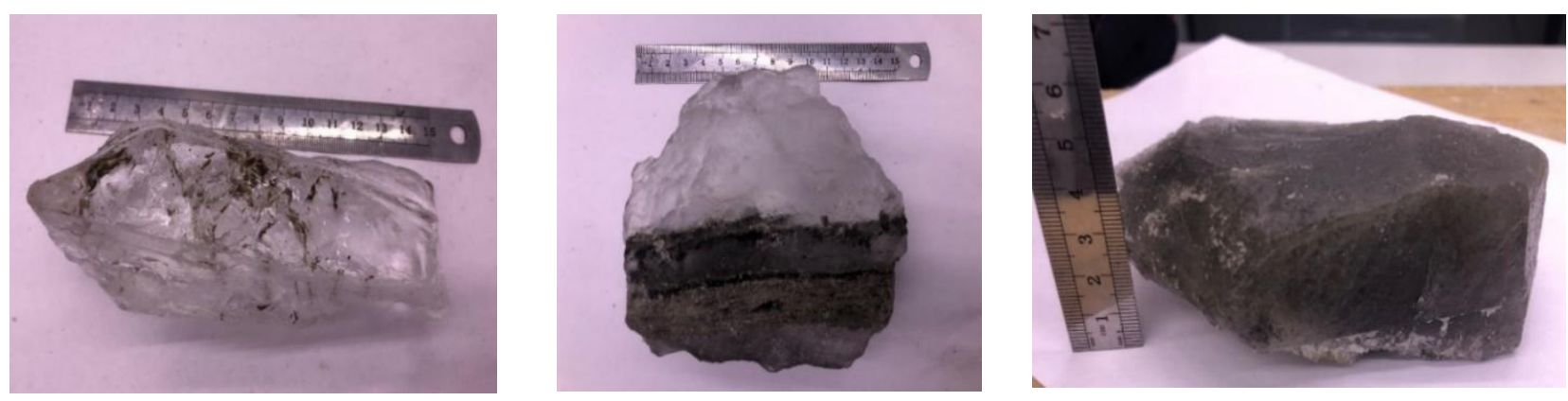

Figure 5. Ice samples from the walls of the crater (C12) found in summer 2017 in the Erkuta River valley, southern Yamal.

Most of the known gas emission craters in the shallow permafrost of northern West Siberia, as well as the exposed thick massive ice, may be related to neotectonic structures. As observed previously [31], permafrost above anticlinal uplifts is thinner due to deep heat flux, while the mean annual temperatures, thicknesses, and ice contents of the permafrost correlate with the pattern of neotectonic motions. Furthermore, heaves and gas emission craters show a probabilistic relationship with the distribution of large neotectonic features. Gas from reservoirs located above neotectonic uplifts and troughs may rise into the overlying sediments [56]. Gas reservoirs under thick Upper Cretaceous mudrocks possibly formed as methane from the mantle and Permian-Triassic coal-bearing sediments migrated over millions of years through faulted crust and accumulated in Cenomanian anticlinal folds. Having filled up the traps, the gas rose further through neotectonic faults and fractures in the caps. In this way, deep gas can be released over a long period to accumulate in shallow Quaternary strata, including in permafrost [47]. Geochemical studies around some gas fields in northern West Siberia show that fluids of hydrocarbon gases from reservoirs can penetrate into shallow permafrost as vertical jets, even though the rocks usually are considered impermeable [62,63]. However, recent data confirm that permafrost is not always a tight barrier for natural gas [64-66]. Therefore, the classical idea that frozen ground would obstruct gas flow is valid only for low-temperature ice-rich permafrost. Experiments reveal greater permeability in warmer and saline permafrost [64] and ice [67], as well as increasing thermal deformation of gas-saturated permafrost [65]. Thus, the warming of permafrost in the gas provinces of northern West Siberia, under a combined action of heat flux from deep gas reservoirs and gas release from shallow permafrost, can produce additional gas migration pathways, as the permafrost becomes less dense and loses its sealing capacity.

\section{Possible Shallow Factors in the Formation of Gas Emission Craters}

Recent data reveal a number of features and patterns common to all, or at least several, known explosive gas emission event in the Arctic tundra of northern West Siberia [13,14,25]. The origin of gas emission craters has been explained by several models. Some are based on evidence from specific craters extrapolated to others already in existing and even future craters, while others aim to explain all known events of this kind.

Gas emission from permafrost, along with the ensuing crater formation, appears to have a certain combination of triggers, as well as several mechanisms that govern and maintain the process. The effect of each trigger and the contribution of each mechanism may change as a function of specific cryological conditions. We modeled the formation of a crater within a back-freezing talik to assess the case of the Erkuta crater in the Yamal Peninsula [26] and synthesized conceptual models of the causative gas accumulation under confining pressure [28]. However, not all craters are related to zones of gas accumulation in former sublake taliks, and those located on high terraces above the floodplain [29] require other explanations [30]. 
The craters outside floodplains and dry lakes, which were examined soon after their formation and prior to inundation, exposed underground ice down to the crater bottom $[17,26,29]$. They had cylindrical shapes with vertical walls, often pitted, and some even had cave-like off-shoots near the base of the ice $[29,68]$.

According to classical views, ice-rich permafrost, with ice filling all pores and cracks, would be a good impermeable trap for gas of any origin; gas migration would be restricted to films of unfrozen water at the boundaries of sediment grains or ice crystals. Similarly, massive ice can also form ideal gas traps due to its rheological properties and ability to rapidly heal any defects that appear; gas migration through water films between ice crystals is minor and decreases with increasing ice crystal sizes. Therefore, the large bodies of massive ice can actually form huge impermeable confining beds and, at the same time, enclose gas traps in ice-free cavities.

Large cavities in ice can arise in different ways. Vertical cylindrical cavities form under the effect of gas fluids rising from subpermafrost reservoirs through fractures or faults [30]. Otherwise, cavities at the base of thick ice beds may result from ice melting by warm flows ascending from below and accommodate deep gas making a gas pocket. If the gas influx is moderate and the cap is solid enough, gas fluids can accumulate for a long time inside the cavity without leaving traces on the ground surface (heaving). However, such a slow process can abruptly turn to an irreversible catastrophic event under a combination of jointly arising triggers. The climate-driven warming of permafrost through the recent decades decreases its mechanical strength from above, while the permafrost base becomes ever shallower as a result of heat flow from underlying gas pools. The continuing accumulation of gas inside the cavity gradually increases pressure in the closed volume. The pressure release may be directed upwards, to the top of the ice bed top and overlying frozen ground, which becomes weaker and more susceptible to yielding due to heat coming simultaneously from above and below. The oval dimples in the ice walls of the crater (Figure $4 \mathrm{~b}$ ) may be due to uneven local ice melting while the gas pocket was forming.

Note that high heat flux leading to permafrost thaw from below may also come from an oil accumulation. The Yamal Peninsula is known to store large amounts of hydrocarbons, and the crater sites can lie over gas or oil reservoirs that maintain the upward heat flux [30].

Gas produced by the dissociation of metastable intrapermafrost gas hydrates triggered by higher local heat flux under the climate warming conditions may provide additional inputs to gas pockets in shallow permafrost at potential sites of explosive gas emission. The increase in the gas permeability of degrading permafrost, with ensuing decomposition of gas hydrates in degraded zones, has been confirmed experimentally [64,69]. Gas liberated from hydrates ascends through permafrost, as well as through cryopegs, thus creating domains saturated with gas and water. As proven by the experiments, metastable gas hydrates dissociate with even minor warming of zones of hydrate-bearing frozen sediments at low negative temperatures [54,70-72]. Northern West Siberia, including the Yamal Peninsula, has already experienced climatic warming events in the past: e.g., January temperatures in the Late Pleistocene and July temperatures in the Holocene at $67^{\circ}-70^{\circ} \mathrm{N}$ were $4-5^{\circ} \mathrm{C}$ higher than the respective present values [73], which apparently led to permafrost degradation. Therefore, it is reasonable to hypothesize that active gas emission from permafrost occurred in the past as well.

Intrapermafrost cryopegs, which can be widely distributed in degrading and more permeable permafrost, can also be responsible for the large gas-filled cavities in underground ice. Depending on the brine-permafrost temperature difference, either the brine cools down to freezing at the permafrost interface or the ice melts and dilutes the cryopeg water. Cryopegs can migrate through permafrost and interact with ice in permeable zones produced by neotectonic deformation. Since ice and water have different specific volumes, ice interacting with saline water can melt locally and develop cavities that trap intrapermafrost and deep gas. Further pressure-driven expulsion of cryopegs causes expansion of 
gas accumulations in the cavities, which may explain the origin of deep caves in the ice walls (Figure 3a) visible near the crater bottom [17,29].

In comparison, the development of caves in permafrost and the accumulation of gas may have additional anthropogenic causes associated with petroleum development along with an ensuing increase in rock stress and microseismicity.

The process of gas-filled cavity formation at the base of a ground ice body interacting with a cryopeg can develop in several stages (Figure 6). It begins with climate warming and degradation of permafrost (stage I) producing permeable zones conducive to migrating gas, which accumulates in shallow permafrost, including in cryopegs that interact with ground ice. Further degradation of permafrost and melting of ground ice interacting with cryopegs at stage II allow a cryopeg to intrude into the ice, while gas ascends through the permeable zone and saturates the cryopeg. At stage III, the ascending gas accumulates in the free space, that forms in the place of molten ice due to the difference in specific volumes between ice and water. The gas fluids include gas that is liberated by the dissociation of intrapermafrost gas hydrates and the component from cryopegs. As shown by experiments, metastable gas hydrates in permafrost can dissociate under thermal effects even at temperatures much below the melting point of pore ice [71]. Furthermore, experiments at negative temperatures reveal active decomposition of pore gas hydrates in permafrost, with the release of abundant hydrate-forming gas (methane) as salt moves from saline water into a frozen hydrate-bearing sample [72]. Note that the cryopegs may wander either due to higher permeability of degrading permafrost or to the expulsion of saline water from the cavity by increasing gas pressure. The gas pressure increases as a result of continuing influx of deep gas, as well as gas liberated from dissociating gas hydrates. The progressively more pressurized gas-filled cavity in the ice is subject to viscoplastic deformation and changes its shape and size (stage IV). Also, the size and surface area of cryopegs may increase as a result of permafrost warming and water inputs from melting ice and dissociating gas hydrates. Then further changes of the gas-filled cavity lad to local deformation and heaving of the permafrost cap (stage $V$ ). Finally, the pressurized gas in the cavity breaks down the frozen cap, which has lost its mechanical strength, and releases explosively, whereby the surface caves in, forming a crater while fragments of permafrost and ice are ejected (stage VI).

Gas inputs through systems of vertical fractures and faults may continue after the eruption and crater formation. Correspondingly, gas of deep-seated origin (judging by its composition) may keep releasing through bottom sediments for some time, although the cap fragments sometimes partly block the conduits and obstruct gas flow [30].

It should be noted that the presented scheme of models does not reflect some important factors causing permafrost degradation and a crater's formation. These factors are soil temperature increasing due to climatic changes and the thermal effect of deep oil and gas formations. However, we always refer to them at all discussed stages of our model as a constant background feature. 
I

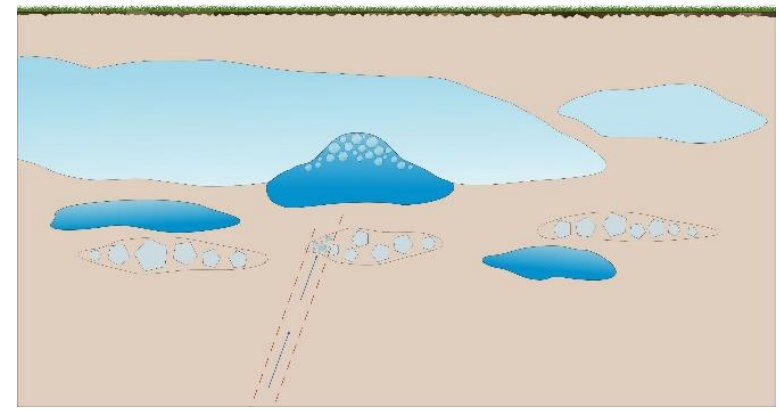

III

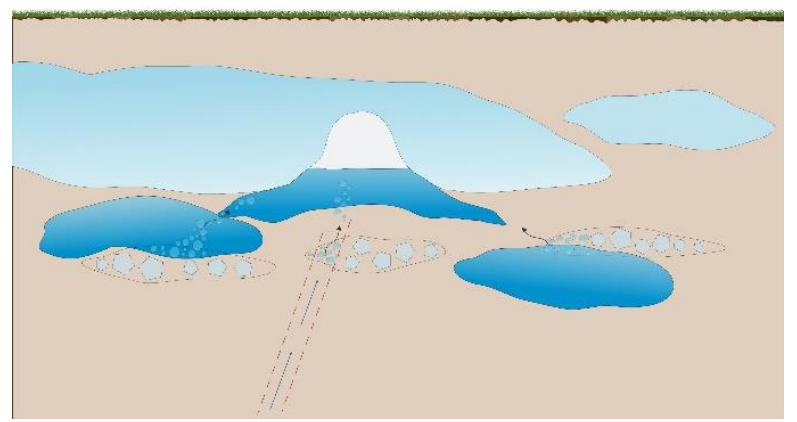

\section{$\mathrm{V}$}

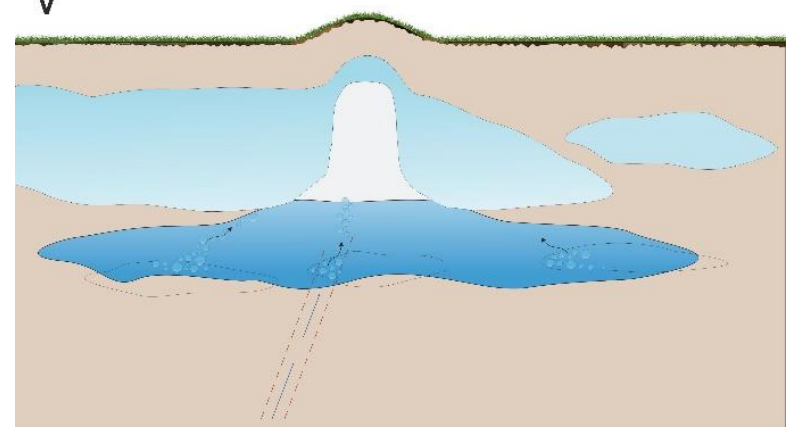

Permafrost Ground
Ice

Cryopeg
II

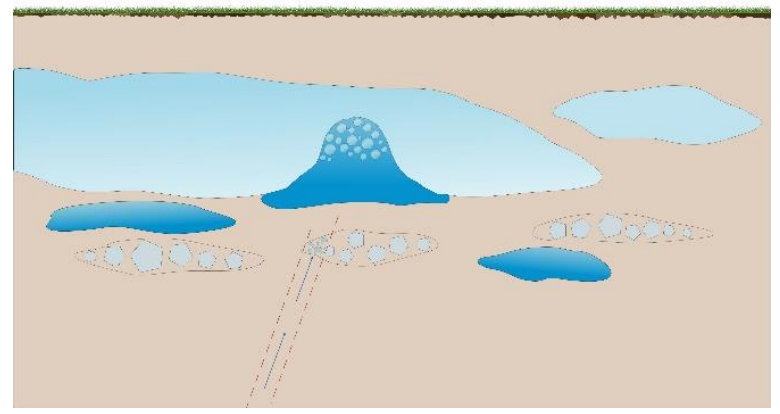

IV

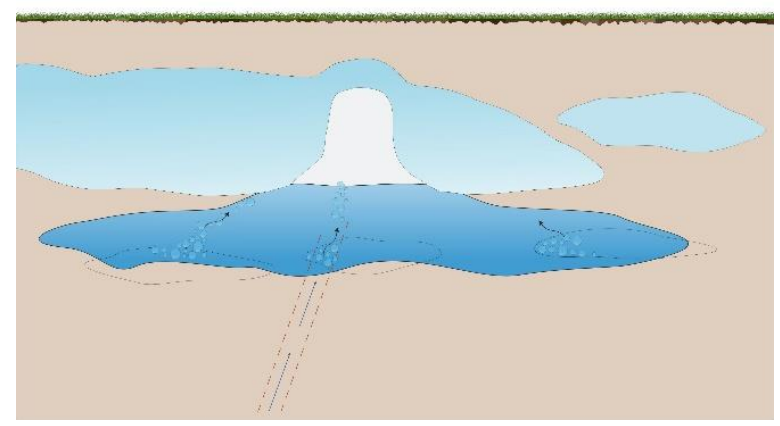

\section{VI}

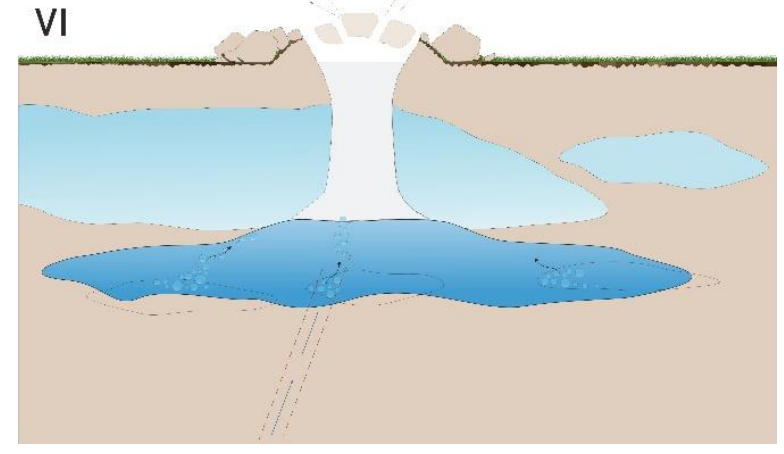

Accumulated gas

-.... Gas Flow Direction

Figure 6. This history of a gas emission crater in shallow permafrost. (I): initiation of ice-cryopeg interaction and accumulation of gas rising through a permeable zone; (II): climate-driven active melting of ice and gas saturation of the thaw zone occupied by the cryopeg; (III): beginning of cavity formation in the thaw zone, with active ascent of gas fluids and wandering of intrapermafrost cryopegs; (IV): size and shape changes of the gas-filled cavity in ice under the effect of: increasing gas pressure, permafrost degradation, wandering of cryopegs, and dissociation of intrapermafrost gas hydrates; (V): further transformation of the gas-filled cavity and heaving; (VI): explosive gas emission, with formation of a crater and dispersal of ice and permafrost fragments. Dashed lines in all panels confine permeable zones; arrows show gas flow direction.

\section{Conclusions}

The huge gas emission craters recently discovered in the Arctic tundra of northern West Siberia are due not only to the active economic development of the area but also to global change, especially warming which leads to thawing of shallow permafrost and creates additional geocryological hazards. The craters form under a certain combination of cryological and geological conditions, in gas-saturated permafrost that encloses thick massive ground ice and cryopegs (intra- and subpermafrost lenses of saline cold water), in the presence of large gas fields and related ascending gas-water fluids. Such conditions exist currently in some areas of northern West Siberia (Yamal and Gydan peninsulas), but this 
combination of factors does not always occur elsewhere in the Arctic. Therefore, explosive gas release is not a ubiquitous phenomenon in the permafrost of Eurasia and North America. Such events also may have occurred in previous periods of climate warming in the geological past of northern West Siberia (e.g., Holocene), while the ancient craters apparently transformed into the round lakes frequently found in the Yamal Peninsula.

The study of permafrost and local geology in the area of recent crater $\mathrm{C} 17$ demonstrates that climate-driven processes in shallow permafrost affect the gas emission patterns and act jointly with the deep factors associated with permafrost history. The suggested conceptual formation models of gas emission craters provide clues to the causes and conditions responsible for the origin of gas-filled cavities in permafrost, to the role of massive ice and intrapermafrost cryopegs in the process, as well as to the potential of gas accumulation, including migration of deep gas and the dissociation of self-preserved metastable gas hydrates. The model also accounts for the role of warming in the deformation of permafrost and ground ice as a prerequisite for the failure of permafrost caps above gas pools and the formation of craters.

The gas emission craters in the Arctic permafrost originate in the presence of:

- gas-filled cavities in ground ice caused by climate warming;

- $\quad$ rich sources of gas that can migrate and accumulate under pressure in the cavities;

- $\quad$ intrapermafrost gas-water fluids that circulate more rapidly in degrading permafrost;

- weak permafrost caps over gas pools.

At the time being, no all-encompassing hypothesis has been proposed that explains all known cases of explosive gas emission in the Arctic permafrost. However, timely purposeful studies of new craters using test drilling down to the permafrost bottom may provide further insights into their formation mechanisms as a basis for prediction and mitigation of the hazard in the developed Arctic regions.

Author Contributions: Contributions: Conceptualization, methodology, supervision, E.M.C.; organization and field work, E.M.C., B.A.B., M.Y.S.; project administration, E.M.C., M.Y.S.; writing-original draft preparation, E.M.C., N.S.S.; writing—review and editing, E.M.C., N.S.S., B.A.B., D.A.D., M.Y.S.; visualization, D.A.D. All authors have read and agreed to the published version of the manuscript.

Funding: This research was supported by the Russian Foundation for Basic Research (grant 19-5551001), the Russian Science Foundation (grants 21-77-10074 and 21-77-30001).

Institutional Review Board Statement: Not applicable.

Informed Consent Statement: Not applicable.

Data Availability Statement: Not Applicable.

Acknowledgments: The authors are grateful to the Government of the Yamal-Nenets Autonomous District and the Russian Center of the Arctic Development for their assistance in conducting field studies, and the energy company Total Energies for supporting research on gas craters in the Russian Arctic. Personal acknowledgments to Professor Vasily Bogoyavlensky for organizing the field trip to the Yamal Peninsula in 2020.

Conflicts of Interest: The authors declare no conflict of interest.

\section{References}

1. Pavlov, A.V. Permafrost and climate monitoring in Russia: Methods, results, and predictions. Kriosf. Zemli 1997, 1, 47-58.

2. Vasiliev, A.A.; Drozdov, D.S.; Moskalenko, N.G. Permafrost temperature dynamics of West Siberia in context of climate changes. Kriosf. Zemli 2008, 7, 10-18.

3. Vasiliev, A.A.; Gravis, A.G.; Gubarkov, A.A.; Drozdov, D.S.; Korostelev, Y.V.; Malkova, G.V.; Oblogov, G.E.; Ponomareva, O.E.; Sadurtdinov, M.R.; Streletskaya, I.D.; et al. Permafrost degradation: Results of long-term geocryological monitoring in the western sector of the Russian Arctic. Earths Cryosphere 2020, 24, 15-30.

4. Streletskiy, D.A.; Sherstiukov, A.B.; Frauenfeld, O.W.; Nelson, F.E. Changes in the 1963-2013 shallow ground thermal regime in Russian permafrost regions. Environ. Res. Lett. 2015, 10, 125005. [CrossRef]

5. Kaverin, D.A.; Pastukhov, A.V.; Novakovsky, A.B. Active layer thickness dynamics in the tundra permafrost-affected soils: A CALM site study, the European North of Russia. Earths Cryosphere 2017, 21, 35-44. 
6. Are, F.E. The problem of deep gas emission into the atmosphere. Kriosf. Zemli 1998, 2, 42-50.

7. Yakushev, V.S.; Chuvilin, E.M. Natural gas and hydrate accumulation within permafrost in Russia. Cold Reg. Sci. Technol. 2000, 149, 46-50. [CrossRef]

8. Andersland, O.B.; Ladanyi, B. Frozen Ground Engineering, 2nd ed.; John Wiley: New York, NY, USA, $2003 ;$ p. 363. ISBN 978-0-471-61549-1.

9. Chuvilin, E.M.; Perlova, E.V.; Baranov, Y.B.; Kondakov, V.V.; Osokin, A.B.; Yakushev, V.S. The Structure and Properties of Permafrost in the Southern Part of the Bovanenkovo Gas-Condensate Field; GEOS: Moscow, Russia, 2007; p. 137.

10. Perlova, E.V.; Miklyaeva, E.S.; Leonov, S.A.; Tkacheva, E.V.; Ukhova, Y.A. Gas hydrates of the Yamal Peninsula and the adjacent shelf of the Kara Sea as a complicating factor in the development of the region. Vesti Gazov. Nauki 2017, 3, $255-261$.

11. Harris, S.A.; Brouchkov, A.; Goudong, C. Geocryology. Characteristics and Use of Frozen Ground and Permafrost Landforms; CRC Press, Taylor \& Francis Group: London, UK, 2018; p. 765. [CrossRef]

12. Hjort, J.; Karjalainen, O.; Aalto, J.; Westermann, S.; Romanovsky, V.E.; Nelson, F.E.; Etzelmüller, B.; Luoto, M. Degrading permafrost puts Arctic infrastructure at risk by mid-century. Nat. Commun. 2018, 9, 5147. [CrossRef]

13. Chuvilin, E.; Ekimova, V.; Davletshina, D.; Sokolova, N.; Bukhanov, B. Evidence of gas emissions from permafrost in the Russian Arctic. Geosciences 2020, 10, 383. [CrossRef]

14. Bogoyavlensky, V.I. Natural and technogenic threats in fossil fuels production in the Earth cryolithosphere. Gorn. Promyshlennost 2020, 1, 97-118. [CrossRef]

15. Bogoyavlensky, V.I. The threat of catastrophic gas blowouts forms the Arctic permafrost. The craters of Yamal and Taymyr. Buren. Neft 2014, 9, 13-18.

16. Leibman, M.O.; Kizyakov, A.I.; Plekhanov, A.V.; Streletskaya, I.D. New permafrost feature-Deep crater in Central Yamal, West Siberia, Russia, as a response to local climate fluctuations. Geogr. Environ. Sustain. 2014, 7, 68-80. [CrossRef]

17. Kizyakov, A.I.; Sonyushkin, A.V.; Leibman, M.O.; Zimin, M.V.; Khomutov, A.V. Geomorphological conditions of the gas-emission crater and its dynamics in Central Yamal. Earths Cryosphere 2015, 19, 15-25.

18. Kizyakov, A.; Khomutov, A.; Zimin, M.; Khairullin, R.; Babkina, E.; Dvornikov, Y.; Leibman, M. Microrelief associated with gas emission craters: Remote-sensing and field-based study. Remote Sens. 2018, 10, 677. [CrossRef]

19. Olenchenko, V.V.; Sinitsky, A.I.; Antonov, E.Y.; Eltsov, I.N.; Kushnarenko, O.N.; Plotnikov, A.E.; Potapov, V.V.; Epov, M.I. Results of geophysical researches of the area of new geological formation "Yamal crater". Earths Cryosphere 2015, 19, 94-106.

20. Bogoyavlenskiy, V.I.; Bogoyavlenskiy, I.V.; Nikonov, R.A. Results of aerial, space, and field studies of large gas blowouts near Bovanenkovo field on Yamal Peninsula. Arkt. Ekol. Ekon. 2017, 3, 4-17.

21. Bogoyavlensky, V.I.; Sizov, O.S.; Bogoyavlensky, I.V.; Nikonov, R.A.; Kargina, T.N. Earth degassing in the Arctic: Comprehensive studies of the distribution of frost mounds and thermokarst lakes with gas blowout craters on the Yamal Peninsula. Arkt. Ekol. Ekon. 2019, 4, 52-68. [CrossRef]

22. Bogoyavlensky, V.; Bogoyavlensky, I.; Nikonov, R.; Kishankov, A. Complex of geophysical studies of the Seyakha catastrophic gas blowout crater on the Yamal Peninsula, Russian Arctic. Geosciences 2020, 10, 215. [CrossRef]

23. Buldovicz, S.N.; Khilimonyuk, V.Z.; Bychkov, A.Y.; Ospennikov, E.N.; Vorobyev, S.A.; Gunar, A.Y.; Gorshkov, E.I.; Chuvilin, E.M.; Cherbunina, M.Y.; Kotov, P.I.; et al. Cryovolcanism on the Earth: Origin of a spectacular crater in the Yamal Peninsula (Russia). Sci. Rep. 2018, 8, 13534. [CrossRef]

24. Dvornikov, Y.A.; Leibman, M.O.; Khomutov, A.V.; Kizyakov, A.I.; Semenov, P.; Bussmann, I.; Babkin, E.M.; Heim, B.; Portnov, A.; Babkina, E.A.; et al. Gas-emission craters of the Yamal and Gydan peninsulas: A proposed mechanism for lake genesis and development of permafrost landscapes. Permafr. Periglac. Process. 2019, 30, 146-162. [CrossRef]

25. Khimenkov, A.N.; Sergeev, D.O.; Vlasov, A.N.; Volkov-Bogorodsky, D.B. Explosive processes in the area of permafrost distribution are a new type of permafrost hazard. Geoecol. Eng. Geol. Hydrogeol. Geocryol. 2019, 6, 30-41. [CrossRef]

26. Chuvilin, E.; Stanilovskaya, J.; Titovsky, A.; Sinitsky, A.; Sokolova, N.; Bukhanov, B.; Spasennykh, M.; Cheremisin, A.; Grebenkin, S.; Davletshina, D.; et al. A Gas-emission crater in the Erkuta River valley, Yamal Peninsula: Characteristics and potential formation model. Geosciences 2020, 10, 170. [CrossRef]

27. Bogoyavlensky, V.I.; Garagash, I.A. Formation of gas emission craters in the Arctic: Support from mathematical modeling. Arkt. Ekol. Ekon. 2015, 3, 12-17.

28. Chuvilin, E.; Sokolova, N.; Davletshina, D.; Bukhanov, B.; Stanilovskaya, J.; Badetz, C.; Spasennykh, M. Conceptual models of gas accumulation in the shallow permafrost of Northern West Siberia and conditions for explosive gas emissions. Geosciences 2020, 10, 195. [CrossRef]

29. Bogoyavlensky, V.; Bogoyavlensky, I.; Nikonov, R.; Kargina, T.; Chuvilin, E.; Bukhanov, B.; Umnikov, A. New catastrophic gas blowout and giant crater on the Yamal Peninsula in 2020: Results of the expedition and data processing. Geosciences 2021, 11, 71. [CrossRef]

30. Bogoyavlensky, V.I. Fundamental aspects of the catastrophic gas blowout genesis and the formation of giant craters in the Arctic. Arkt. Ekol. Ekon. 2021, 11, 51-66. [CrossRef]

31. Baulin, V.V. Permafrost in Petroleum Provinces of the USSR; Nedra: Moscow, Russia, 1985; p. 176.

32. Ershov, E.D. Geocryology of the USSR. Western Siberia; Nedra: Moscow, Russia, 1989; p. 454. ISBN 5-247-00432-9. (In Russian) 
33. Baulin, V.V.; Aksenov, V.I.; Dubikov, G.I.; Rivkin, F.M. Geocryological Conditions of the Bovanenkovo Gas.-Condensate Field. Book 2. In Engineering Geological Monitoring in the Petroleum Production Areas of the Yamal Peninsula; Tsybulsky, V.R., Ed.; IPOS: Tyumen, Russia, 1996; p. 232.

34. Melnikov, E.S.; Grechishchev, S.E. Permafrost and Petroleum Development; GEOS: Moscow, Russia, 2002 ; p. 402.

35. Badu, Y.V.; Gafarov, N.A.; Podborny, E.E. Permafrost in Oil-Gas-Condensate Fields of the Yamal Peninsula. Book 2. Permafrost in the Bovanenkovo Field; Gazprom Expo: Moscow, Russia, 2013; p. 424.

36. Parmuzin, S.; Sukhodolsky, S.E. Massive ice in the central Yamal Peninsula and its effect on surface topography. In Massive Ice in Permafrost; Knizhnoye Izdatelstvo: Yakutsk, Russia, 1982; pp. 51-61.

37. Dubikov, G.I. Genetic relations of ground ice and permafrost in West. Siberia. In Ground Ice in Permafrost Regions; IM SO AN SSSR: Yakutsk, Russia, 1982; pp. 24-42.

38. Dubikov, G.I. Composition and Cryostratigraphy of Permafrost in West Siberia; GEOS: Moscow, Russia, $2002 ;$ p. 246.

39. Fotiev, S.M. Formation patterns of the major-ion chemistry of natural waters in the Yamal Peninsula. Kriosf. Zemli 1999, 3, 40-65.

40. Anisimova, N.P.; Kritsuk, L.N. The genesis of ground ice: Evidence from cryo-hydrochemical data. In Problems of Geocryology; Nauka: Moscow, Russia, 1983; pp. 230-239.

41. Danilov, I.D. Massive ice and genesis of subsea permafrost. In Geocryological Research; Moscow University: Moscow, Russia, 1989; pp. 16-29.

42. Kritsuk, L.N. Ground Ice in West. Siberia; Nauchnyi Mir: Moscow, Russia, 2010; p. 352.

43. Fotiev, S.M. Chemical composition and genesis of water that formed the repeatedly injected massive ice beds on the area of the Bovanenkovo deposit. Earths Cryosphere 2012, 16, 3-28.

44. Belova, N.G. Massive Ice Beds in the Southwestern Coast of the Kara Sea; MAKS Press: Moscow, Russia, $2014 ;$ p. 180.

45. Dubikov, G.I.; Koreisha, M.M. Fossil intrusive ice in the Yamal Peninsula. Izv. AN SSSR Ser. Geogr. 1964, 5, 58-65.

46. Fotiev, S.M. Mechanism of formation of injective ice veins and hydrolaccoliths. Kriosf. Zemli 2011, 15, 44-55.

47. Badu, Y.B. Effects of Gas Accumulations on the Orign and Evolution of Permafrost in Gas Reservoirs of the Yamal Peninsula; Nauchnyi Mir: Moscow, Russia, 2018; p. 232.

48. Fotiev, S.M. Estimation of ground paleotemperatures in the Arctic coast by the hydrochemical method. Kriosf. Zemli 1997, 1, 29-35.

49. Chuvilin, E.M.; Yakushev, V.S.; Perlova, E.V.; Kondakov, V.V. The gas component of permafrost in the Bovanenkovo gas-condensate field (Yamal Peninsula). Dokl. Akad. Nauk 1999, 369, 522-524.

50. Yakushev, V.S.; Perlova, E.V.; Chuvilin, E.M.; Kondakov, V.V. Permafrost as a storage of gas and gas hydrate accumulations. Gazov. Promyshlennost 2003, 3, 36-40.

51. Ershov, E.D.; Lebedenko, Y.P.; Chuvilin, E.M.; Istomin, V.A.; Yakushev, V.S. Specific conditions of the existence of gas hydrates in permafrost. Dokl. Akad. Nauk 1991, 321, 788-791.

52. Dallimore, S.R.; Chuvilin, E.M.; Yakushev, V.S. Field and laboratory characterization of intrapermafrost gas hydrates, Mackenzie Delta, NWT, Canada. In Proceedings of the 2nd Nternational Conference on Natural Gaz Hydrates, Toulouse, France, 2-6 June 1996; pp. 525-531.

53. Chuvilin, E.M.; Yakushev, V.S. Structure and some properties of frozen hydrate containing soils. In Proceedings of the Japan National Oil Corporation (JNOC) International Symposium on Methane Hydrates-Resources in the Near Future, Tokyo, Japan, 20-22 October 1998; p. 239.

54. Chuvilin, E.M.; Guryeva, O.M. Experimental study of self-preservation effect of gas hydrates in frozen sediments. In Proceedings of the 9th International Conference on Permafrost, Fairbanks, Alaska, 23 June-3 July 2008; pp. 263-267.

55. Chuvilin, E.; Bukhanov, B.; Davletshina, D.; Grebenkin, S.; Istomin, V. Dissociation and self-preservation of gas hydrates in permafrost. Geosciences 2018, 8, 431. [CrossRef]

56. Badu, Y.B.; Nikitin, K.A. Frost mounds within the gas-bearing structures areas, northern part of West Siberia. Earths Cryosphere 2020, 21, 21-32.

57. Kritsuk, L.N. Genesis of ground ice in West Siberia: Mapping issues. Mater. Glaciol. Issled. 1985, 54, $188-192$.

58. Shumsky, P.A. Ground Ice, Fundamentals of Geocryology Book 1; AN SSSR: Moscow, Russia, 1959; pp. $274-327$.

59. Roth, L.; Saur, J.; Retherford, K.; Strobel, D.; Feldman, P.; McGrath, M.; Nimmo, F. Transient water vapor at Europa's South Pole. Science 2014, 343, 171-174. [CrossRef] [PubMed]

60. Soare, R.J.; Conway, S.J.; Dohm, J.M.; El-Maarry, M.R. Possible open-system (hydraulic) pingos in and around the Argyre impact region of Mars. Earth Planet. Sci. Lett. 2014, 398, 25-36. [CrossRef]

61. Shumsky, P.A. Fundamentals of Structural Ice Science; AN SSSR: Moscow, Russia, 1955; p. 492.

62. Bordukov, K. Geochemical Fields in the Permafrost Area of the Western Yenisei-Khatanga Basin: Implications for Petroleum Exploration. Author's Abstract, Candidate Thesis (Geology EMineralogy); VNIIYaGG: Moscow, Russia, 1985; p. 24.

63. Zavatsky, M.D. Fields of Hydrocarbon Gases in Natural Surface Adsorbents: Investigation for Petroleum Exploration in West Siberia. Author's Abstract, Candidate Thesis (Geology EMineralogy); Tyumen Petroleum University: Tyumen, Russia, 2009 ; p. 23.

64. Chuvilin, E.M.; Grebenkin, S.I.; Sacleux, M. Influence of moisture content on permeability of sandy soils in frozen and unfrozen states. Earths Cryosphere 2016, 20, 71-78.

65. Khimenkov, A.N.; Koshurnikov, A.V.; Karpenko, F.S.; Kutergin, V.N.; Gagarin, V.E.; Sobolev, P.A. Gas infiltration into permafrost in the context to lithosphere degassing and origin of natural gas blowouts in permafrost. Arkt. Antarkt. 2019, 3, 16-18. [CrossRef] 
66. Yakushev, V.S. Development problems caused by gas saturated permafrost in gas fields of the Yamal Peninsula. Ross. Gazov. Obs. Nauchnyi Zhurnal 2019, 3-4, 49-53.

67. Roman, L.T.; Merzlyakov, V.P.; Maleeva, A.N. Thermal deformation of frozen soils: Role of water and gas saturation. Earth's Cryosphere 2017, 21, 24-31. [CrossRef]

68. Streletskaya, I.D.; Leibman, M.O.; Kizyakov, A.I.; Oblogov, G.E.; Vasiliev, A.A.; Khomutov, A.V.; Dvornikov, Y.A. Ground ice and its role in the formation of a gas-emission crater in the Yamal Peninsula. Mosc. Univ. Bull. Ser. 2017, 5, 91-99.

69. Chuvilin, E.; Grebenkin, S.; Zhmaev, M. Gas permeability of sandy sediments: Effects of phase changes in pore ice and gas hydrates. Energy Fuels 2021, 35, 7874-7882. [CrossRef]

70. Yakushev, V.S.; Semenov, A.P.; Bogoyavlensky, V.I.; Medvedev, V.I.; Bogoyavlensky, I.V. Experimental modeling of methane release from intrapermafrost relic gas hydrates when sediment temperature change. Cold Reg. Sci. Technol. 2018, 149, 46-50. [CrossRef]

71. Chuvilin, E.; Ekimova, V.; Bukhanov, B.; Grebenkin, S.; Shakhova, N.; Semiletov, I. Role of salt migration in destabilization of intrapermafrost hydrates in the Arctic shelf: Experimental modeling. Geosciences 2019, 9, 188. [CrossRef]

72. Chuvilin, E.; Davletshina, D.; Ekimova, V.; Bukhanov, B.; Shakhova, N.; Semiletov, I. Role of warming in destabilization of intrapermafrost gas hydrates in the Arctic Shelf: Experimental modeling. Geosciences 2019, 9, 407. [CrossRef]

73. Volkova, V.S.; Kulkova, I.A. Cenozoic climate optimums in West Siberia (from spore-pollen data). Stratigrafiya. Geol. Korrelatsiya 1994, 2, 108-112. 